\title{
Efektivitas Biaya Penggunaan Antibiotik Pasien ISPA Pediatri di RSUD Kajen Kabupaten Pekalongan Tahun 2019
}

\author{
Siti Aliyah ${ }^{1}$, Yulian Wahyu Permadi ${ }^{2 *}$, St. Rahmatullah ${ }^{3}$, Ainun Mutoharoh ${ }^{4}$ \\ 1,2,3,4 Program Studi Sarjana Farmasi, Fakultas Ilmu Kesehatan, Universitas Muhammadiyah \\ Pekajangan Pekalongan \\ *email: y.wahyu.permadi@umpp.ac.id
}

\begin{abstract}
Acute respiratory infection (ARI) is an acute infectious disease that attacks one or more parts of the respiratory system, starting from the nasal alveoli, including the adnexa (sinus of the pleural middle ear cavity). The purpose of this study was to determine the type of antibiotics in pediatric ARI patients at Kajen Hospital in 2019 and to determine the effectiveness of treatment costs based on the use of antibiotics issued by pediatric ARI patients at Kajen Hospital in 2019. This study is a type of non-experimental research that is descriptive and takes retrospectively through medical record data of ARI patients. The number of samples used as many as 80 patients. The pharmacoeconomic method used in this study is the CEA method/cost effectiveness analysis. The data taken include: data on respondent characteristics, total costs or direct medical costs, the results of the study on the effectiveness of antibiotic therapy Cefotaxim 52.90\%, Efotax $54.50 \%$ and Viccillin $61.50 \%$. The average total cost of antibiotics for Cefotaxim was Rp. 817,392, Efotax was Rp. $1,392,189$, Viccillin was Rp. 1,318,838, Ampicillin was Rp. 1,107,059, Cefadroxil was Rp. 850,564 and Cefixim was Rp. 858,479. The ACER value was the most cost effective for Cefotaxim compared to other therapies. while the ICER value is the most cost effective, namely the comparison between Cefotaxim and Viccillin with an ICER value of Rp $63,081,937$. Suggestions for further research are expected to be able to compare the cost of treatment for outpatients and inpatients and increase sampledata.
\end{abstract}

Keywords: Cost Effectiviness, ARI, antibiotik

\begin{abstract}
Abstrak
Infeksi saluran pernafasan akut (ISPA) merupakan penyakit infeksi akut yang menyerang salah satu / lebih bagian dari sistem pernafasan mulai dari hidung alveoli termasuk adneksanya (sinus rongga telinga tengah pleura). Tujuan penelitian ini adalah untuk mengetahui jenis antibiotik pada pasien ISPA pediatri di RSUD Kajen tahun 2019 dan untuk mengetahui keefektifan biaya pengobatan berdasarkan penggunaan antibiotik yang dikeluarkan oleh pasien ISPA pediatri di RSUD kajen tahun 2019. Penelitian ini merupakan jenis penelitian non eksperimental yang bersifat deskriptif dan pengambilan data secara retrospektif melalui data rekam medik pasien ISPA. Jumlah sampel yang digunakan sebanyak 80 pasien. Metode farmakoekonomi yang digunakan pada penelitian ini yaitu metode CEA/Analisis efektifitas biaya. Data yang diambil meliputi: data karakteristik responden, biaya total atau biaya medik langsung, Hasil penelitian efektivitas terapi antibiotik Cefotaxim $52,90 \%$, Efotax 54,50\% dan Viccillin 61,50\%. Hasil rata-rata total biaya antibiotik Cefotaxim sebesar Rp 817.392, Efotax Rp 1.392.189, Viccillin Rp 1.318.838, Ampicillin Rp 1.107.059, Cefadroxil Rp 850.564 dan Cefixim Rp 858.479. Nilai ACER yang paling cost efffective pada antibiotik Cefotaxim dibandingkan dengan terapi lainnya. sedangkan pada nilai ICER yang paling cost effecttive yaitu pada perbandingan antara Cefotaxim dengan Viccillin dengan nilai ICER Rp - 63.081.937. Saran untuk penelitian selanjutnya diharapkan dapat membandingkan biaya pengobatan pasien rawat jalan dan rawat inap serta memperbanyak data sampel
\end{abstract}

Kata kunci: Efektivitas biaya; ISPA; antibiotik 


\section{Prosiding Seminar Nasional Kesehatan 2021 Lembaga Penelitian dan Pengabdian Masyarakat Universitas Muhammadiyah Pekajangan Pekalongan}

\section{Pendahuluan}

Infeksi saluran pernafasan akut (ISPA) merupakan penyakit infeksi akut yang menyerang salah satu / lebih bagian dari sistem pernafasan mulai dari hidung alveoli termasuk adneksanya (sinus rongga telinga tengah pleura) (Depkes, 2013). ISPA merupakan penyakit yang menyebabkan tingkat morbiditas dan mortilitas tinggi, termasuk pada bayi, anak - anak dan orang lanjut usia (Kemenkes RI, 2011).

Prevalensi ISPA di Provinsi Jawa Tengah pada tahun 2017 sebesar 3,61\%, kasus ISPA di Jawa Tengah lebih besar dibandingkan dengan provinsi lain seperti Bali 2,05\%, Lampung 2,23\% dan Riau 2,67\% (Kementerian Kesehatan RI, 2017). Namun berdasarkan prevalensi ISPA pada tahun 2018 bahwa kasus ISPA di Jawa Tengah mengalami peningkatan yang cukup tinggi yaitu sebesar 8,5\% (Kementrian Kesehatan RI, 2018). Berdasarkan data dari Dinkes Kabupaten Pekalongan pada tahun 2019 bahwa dari 10 besar penyakit yang ada di Kabupaten Pekalongan, ISPA merupakan penyakit nomor 1 dengan kasus sebesar 25.682 (Dinkes Kab. Pekalongan, 2019).

Menurut Kemenkes RI (2017) bahwa kasus ISPA/pneumonia berdasarkan kelompok umur pada balita di Jawa tengah usia $<1$ Tahun dan 1-4 Tahun sebesar 52.033. Jumlah kematian kasus ISPA/pneumonia pada balita yaitu sebanyak 86 . Pada tahun 2018 kasus ISPA pada balita sebesar 62,5\% namun di tahun 2019 mengalami peningkatan sebesar 67,7 \% (Dinkes Prov Jateng, 2019).

Dalam pemberian terapi pada pasien infeksi saluran pernafasan akut obat yang diberikan sangat bervariasi dan lama tinggal atau Length Of Stay (LOS) berhubungan dengan biaya dan efektivitas terapi, sehinggga diperlukan suatu analisis farmakoekonomi dengan tujuan untuk memperoleh efek yang maksimal dari anggaran yang terbatas. Dalam analisis farmakoekonomi dapat memberikan panduan mengenai bagaimana cara yang tepat dalam penggunaan anggaran yang tersedia, serta dapat membantu mengukur antara manfaat dan biaya yang dikeluarkan (Melly, 2015).

Peraturan Menteri Kesehatan Nomor 59 tahun 2014 tentang standar tarif pelayanan kesehatan dalam penyelenggaraan program jaminan kesehatan. Besaran pembayaran klaim oleh Badan Penyelenggara Jaminan Sosial (BPJS) Tarif pelayanan ini sudah termasuk pemakaian obat-obatan dan alat kesehatan terbatasnya anggaran yang tersedia maka diperlukan pemilihan penggunaan obat dengan memperhatikan kendali mutu dan biaya. Penerapan kajian farmakoekonomi dalam pemilihan dan penggunaan obat secara efektif dan efisien sangat dibutuhkan untuk menganalisa biaya obat (Kemenkes RI, 2014). Salah satu kajian farmakoekonomi adalah analisis efektivitas biaya, yaitu dengan membandingkan biaya dan efektivitas alternatif pengobatan sesuai nilai ACER dan ICER

\section{Metode}

Penelitian ini termasuk dalam jenis penelitian non eksperimental yang bersifat deskriptif dan pengambilan data secara retrospektif melalui data rekam medik pasien ISPA. Teknik pengambilan sampel menggunakan teknik Random sampling dimana sampel dihitung menggunakan rumus Slovin (Nalim \& Salafudin, 2012) : 


\section{Prosiding Seminar Nasional Kesehatan 2021 Lembaga Penelitian dan Pengabdian Masyarakat Universitas Muhammadiyah Pekajangan Pekalongan}

$$
\begin{aligned}
\mathrm{N} & =\frac{N}{1+N e^{2}} \\
\text { Keterangan: } & \mathrm{n}=\text { Jumlah sampel } \\
\mathrm{N} & =\text { Jumlah populasi } \\
\mathrm{P} & =\text { Tingkat kesalahan } 10 \%
\end{aligned}
$$

Populasi diperoleh sebanyak 401 pasien berdasarkan perhitungan rumus Slovin didapat 80 pasien yang memenuhi kriteria inklusi, berikut adalah kriteria inklusi dan eksklusi:

\section{Kriteria inklusi}

1. Pasien dengan diagnosa ISPA

2. Pasien BPJS

3. Pasien yang mendapatkan terapi antibiotik tunggal

4. Pasien ISPA dengan rentan usia 0-5 tahun dan 6-11 tahun

5. Pasien dengan tidak mempunyai riwayat penyakit penyerta

\section{Kriteria eksklusi}

1. Pasien pulang paksa atau tidak menyelesaikan perawatan

2. Pasien dengan data yang tidak dapat ditemukan (data RM dan rincian biaya selama perawatan)

3. Pasien dengan data rincian biaya tidak lengkap

\section{Analisis Data}

Data dianalisis secara deskriptif dalam bentuk tabel menggunakan SPSS versi 25 , data yang sudah terkumpul selanjutnya dilakukan perhitungan biaya total. Data ini digunakan untuk menghitung nila ACER dan ICER dengan rumus sebagai berikut (Andayani, 2013):

\section{Perhitungan nilai ACER}

ACER $=$ Biaya rata-rata jenis terapi obat

$$
\text { Efektifitas terapi \% }
$$

\section{Perhitungan nilai ICER}

ICER $=$ Biaya terapi obat $A(R p)-$ Biaya terapi obat $B(R p)$

$$
\text { Efek obat } A(\%) \text { - Efek obat } B(\%)
$$

\section{Hasil dan Pembahasan}

\section{A. Karakteristik Pasien}

\section{Distribusi Pasien Berdasarkan Jenis Kelamin}

Tabel 4.1Distribusi pasien berdasarkan jenis kelamin di RSUD Kajen Kabupaten Pekalongan periode Januari - Desember 2019

\begin{tabular}{cccc}
\hline No & $\begin{array}{c}\text { Jenis } \\
\text { kelamin }\end{array}$ & Jumlah (N) & Persentase (\%) \\
\hline Laki - Laki & 46 & 57,5 \\
: Perempuan & 34 & 42,5 \\
\hline Total & 80 & 100 \\
\hline
\end{tabular}




\section{Distribusi Berdasarkan Umur}

Tabel 4.2 Distribusi umur pasien ISPA di RSUD Kajen Kabupaten Pekalongan periode Januari - Desember 2019

\begin{tabular}{rrrc}
\hline No & Umur & Jumlah (N) & Persentase (\%) \\
\hline $0-5$ tahun & 66 & 82,5 \\
$6-11$ tahun & 14 & 17,5 \\
\hline Total & 80 & 100 \\
\hline
\end{tabular}

\section{Lama Rawat Inap}

Tabel 4.3 Distribusi lama rawat inap pasien ISPA di RSUD Kajen Kabupaten Pekalongan Periode Januari - Desember 2019

\begin{tabular}{cccc}
\hline No & $\begin{array}{c}\text { Lama hari } \\
\text { rawat inap }\end{array}$ & Jumlah pasien & Persentase \% \\
\hline 1 & $2-4$ hari & 27 & 33,8 \\
2 & $5-7$ hari & 42 & 52,5 \\
3 & $8-10$ hari & 11 & 13,8 \\
\hline & Total & 80 & 100 \\
\hline
\end{tabular}

B. Gambaran Pola Pengobatan Pasien Berdasrkan Jenis Antibiotik

Tabel 4.4 Profil penggunaan antibiotik pada pasien ISPA di RSUD Kajen Kabupaten Pekalongan periode Januari - Desember 2019

\begin{tabular}{llcc}
\hline No & Jenis antibiotik & Jumlah (N) & Persentase (\%) \\
\hline 1 & Cefotaxim Injeksi & 51 & 63,7 \\
2 & Efotax & 11 & 13,8 \\
3 & Viccillin Injeksi & 13 & 16,3 \\
4 & Ampicillin injeksi & 1 & 1,3 \\
5 & Cefadroxil syr & 2 & 2,5 \\
6 & Cefixim syr & 2 & 2,5 \\
\hline \multicolumn{2}{l}{ Total } & 80 & $100 \%$
\end{tabular}

\section{Analisis Efektivtias Biaya Penggunaann Terapi Antibiotik Pasien ISPA di RSUD Kajen Kabupaten Pekalongan periode Januari - Desember 2019}

\section{Biaya Antibiotik}

Rata biaya antibiotik pasien ISPA pediatri di RSUD Kajen Kabupaten Pekalongan periode Januari - Desember 2019 dapat dilihat pada tabel 4.5 
Tabel 4.5Rata - rata biaya antibiotik pasien ISPA pediatri di RSUD Kajen Kabupaten Pekalongan periode Januari - Desember 2019

\begin{tabular}{lcc}
\hline Jenis Antibiotik & Jumlah Pasien & Biaya Rata - Rata Antibiotik \\
\hline Cefotaxim Injeksi & 51 & Rp. 31.781 \\
Efotax & 11 & Rp. 278.690 \\
Viccillin Injeksi & 13 & Rp 234.230 \\
Ampicillin injeksi & 1 & Rp. 42.400 \\
Cefadroxil syr & 2 & Rp. 12.800 \\
Cefixim syr & 2 & Rp. 15.200 \\
\hline
\end{tabular}

2. Perhitungan Biaya Medik Langsung Atau Total Biaya

Tabel 4.6 Perhitungan rata - rata total biaya

\begin{tabular}{|c|c|c|c|c|c|c|c|c|}
\hline $\begin{array}{c}\text { Terapi } \\
\text { antihiotik }\end{array}$ & $\begin{array}{c}\text { Biaya } \\
\text { antibiotik } \\
\left(R_{p}\right)\end{array}$ & $\begin{array}{c}\text { Biaya obat } \\
\text { tambahan } \\
\text { (Rp) }\end{array}$ & $\begin{array}{c}\text { Biaya visile } \\
\text { dekter } \\
\text { (Rp) }\end{array}$ & $\begin{array}{c}\text { Biaya } \\
\text { tindakan } \\
\text { medis (Rp) }\end{array}$ & $\begin{array}{c}\text { Blaya } \\
\text { rawat inap } \\
\text { (Rp) }\end{array}$ & $\begin{array}{c}\text { Biaya } \\
\text { Laboraterium } \\
\text { (Rp) }\end{array}$ & $\begin{array}{c}\text { Biaya } \\
\text { AL.KES } \\
\left(K_{p}\right)\end{array}$ & $\begin{array}{l}\text { Biaya } \\
\text { total } \\
\text { (Rp) }\end{array}$ \\
\hline $\begin{array}{l}\text { Cefotaxim } \\
\text { injobasi }\end{array}$ & 31.781 & 409.920 & 135.364 & 142.780 & 319,313 & 86.627 & 162.100 & 817392 \\
\hline Efotax injeksi & 278.690 & 318,870 & 142727 & 87.867 & 364545 & 80.590 & 118,900 & 1392.189 \\
\hline $\begin{array}{l}\text { Viccillin } \\
\text { injeksi }\end{array}$ & 234230 & 316.576 & 141.076 & 99,456 & 344615 & 83.385 & 99.500 & 1318.838 \\
\hline $\begin{array}{l}\text { Ampicillin } \\
\text { injodsi }\end{array}$ & 42.400 & 136.800 & 90.000 & 171.359 & 530.000 & 90.000 & 46.500 & 1.107 .059 \\
\hline $\begin{array}{l}\text { Cefadroxil } \\
\text { sinpp }\end{array}$ & 12.800 & 273,900 & 40.000 & 75.179 & 75,000 & 118.250 & 255,435 & 850.564 \\
\hline Cefixim sirup & 15.200 & 232.850 & 70000 & 75.179 & 270.000 & 111500 & 83.750 & 858.479 \\
\hline
\end{tabular}

\section{Perhitungan Efektivitas Terapi Berdasarkan Lama Rawat Inap}

Tabel 4.7 Persentase ekefektivitas terapi antibiotik pada pasien ISPA di RSUD Kajen Kabupaten Pekalongan periode Januari - Desember 2019

\begin{tabular}{lccc}
\hline \multicolumn{1}{c}{$\begin{array}{c}\text { Terapi } \\
\text { Antibiotik }\end{array}$} & $\begin{array}{c}\text { Jumlah Pasien Yang } \\
\text { Menggunakan } \\
\text { Antibiotik }\end{array}$ & $\begin{array}{c}\text { Jumlah Pasien Yang } \\
\text { Mencapai Target } \\
\text { lama rawat inap }\end{array}$ & $\begin{array}{c}\text { Persentase } \\
\text { (\%) }\end{array}$ \\
\hline Cefotaxim & 51 & 27 & 52,90 \\
Injeksi & 11 & 6 & 54,50 \\
\hline Efotax & 13 & 8 & 61,50 \\
Viccillin Injeksi & 1 & 0 & 0,00 \\
Ampicillin & 2 & 0 & 0,00 \\
Injeksi & 2 & 0 & 0,00 \\
Cefadroxil Sirup & 2 Cefixim & & 0 \\
\hline
\end{tabular}

4. Peritungan Efektivitas Biaya Terapi Antibiotik Pada Pasien ISPA di RSUD Kajen Kabupaten Pekalongan periode Januari - Desember 2019

\section{a. Perhitungan Nilai ACER}

Hasil Nilai ACER penggunaan terapi antibiotik pasien ISPA di RSUD Kajen Kabupaten Pekalongan periode Januari - Desember 2019 dapat dilihat pada tabel 4.8 


\section{Prosiding Seminar Nasional Kesehatan 2021 \\ Lembaga Penelitian dan Pengabdian Masyarakat Universitas Muhammadiyah Pekajangan Pekalongan}

Tabel 4.8 Hasil Nilai ACER penggunaan terapi antibiotik pasien ISPA di RSUD Kajen Kabupaten Pekalongan periode Januari - Desember 2019

\begin{tabular}{llll}
\hline \multicolumn{1}{c}{$\begin{array}{c}\text { Terapi } \\
\text { Antibiotik }\end{array}$} & \multicolumn{1}{c}{$\begin{array}{c}\text { Rata-rata Biaya } \\
\text { Total (Rp) }\end{array}$} & $\begin{array}{c}\text { Efektivitas } \\
(\mathbf{\%})\end{array}$ & $\begin{array}{c}\text { ACER } \\
(\mathbf{R p )}\end{array}$ \\
\hline $\begin{array}{l}\text { Cefotaxim } \\
\text { Injeksi }\end{array}$ & 817.392 & 52,90 & 1.545 .164 \\
Efotax Injeksi & 1.392 .189 & 54,50 & 2.554 .475 \\
Viccillin & 1.318 .838 & 61,5 & 2.144 .452 \\
$\begin{array}{l}\text { Injeksi } \\
\text { Ampicillin }\end{array}$ & 1.107 .059 & 0,00 & 0,00 \\
$\begin{array}{l}\text { Injeksi } \\
\text { Cefdroxil }\end{array}$ & 850.564 & 0,0 & 0,00 \\
$\begin{array}{l}\text { Sirup } \\
\text { Cefixim Sirup }\end{array}$ & 858.479 & 0,0 & 0,00 \\
\hline
\end{tabular}

\section{b. Perhitungan Nilai ICER}

Tabel 4.10 Hasil Nilai ICER penggunaan terapi antibiotik pasien ISPA di RSUD Kajen Kabupaten Pekalongan periode Januari - Desember 2019

\begin{tabular}{|c|c|c|c|c|}
\hline $\begin{array}{c}\text { Terapi } \\
\text { Antibiotik }\end{array}$ & $\begin{array}{c}\text { Rata-rata } \\
\text { Biaya Total } \\
\text { (Rp) }\end{array}$ & $\begin{array}{l}\text { Efektivita } \\
\text { s (\%) }\end{array}$ & $\begin{array}{l}\text { ACER } \\
\text { (Rp) }\end{array}$ & ICER (Rp) \\
\hline $\begin{array}{l}\text { Cefotaxim } \\
\text { Injeksi } \\
\text { Efotax }\end{array}$ & $\begin{array}{l}817.392 \\
1.392 .189\end{array}$ & $\begin{array}{l}52,90 \\
54,50\end{array}$ & $\begin{array}{l}1.545 .164 \\
2.554 .475\end{array}$ & - 63.081.937 \\
\hline $\begin{array}{l}\text { Viccillin } \\
\text { Injeksi } \\
\text { Cefotaxim } \\
\text { Injeksi }\end{array}$ & $\begin{array}{l}1.318 .838 \\
1.500 .911\end{array}$ & $\begin{array}{l}61,5 \\
52,90\end{array}$ & $\begin{array}{l}2.144 .452 \\
1.545 .164\end{array}$ & 6.968 .465 \\
\hline
\end{tabular}

\section{Pembahasan}

Berdasarkan hasil penelusuran data di ruang rekam medis RSUD Kajen Kabupaten Pekalongan diperoleh data rekam medis rawat inap pasien ISPA pediatri periodeJanuari - Desember 2019 sebanyak 80 sampel yang telah memenuhi kriteria inklusi.

Pada data distribusi jenis kelamin dapat dilihat dari hasil Tabel 4.1 diperoleh data jumlah laki - laki sebanyak 46 pasien dan jumlah perempuan sebanyak 34 pasien Hasil ini sejalan dengan penelitian yang dilakukan oleh Salamah (2017) menyatakan bahwa pasien ISPA pediatri paling banyak menyerang pada jenis kelamin laki - laki. Hal ini dikarenakan daya hambat aliran udara pada paru-paru perempuan lebih rendah, serta daya hantar aliran udara lebih tinggi, yang menyebabkan sirkulasi udara pada sistem pernafasan lancar sehingga paru dapat terlindungi oleh patogen (Kaparang, 2014).

Pada data distribusi berdasarkan umur Pada data Tabel 4.2 pasien ISPA dengan rentang usia balita 0 - 5 tahun sebanyak 66 pasien dengan persentase $82,5 \%$ dan pada rentang usia $6-11$ tahun sebanyak 14 pasien dengan persentase $17,5 \%$. Hal ini dapat disebabkan karena adanya sistem imun pada balita masih relatif rendah sehingga pentingnya pemberian imunisasi untuk menjaga imun pada balita agar terhindar dari virus (Nasution, 2020). 


\section{Prosiding Seminar Nasional Kesehatan 2021 Lembaga Penelitian dan Pengabdian Masyarakat Universitas Muhammadiyah Pekajangan Pekalongan}

Pada Tabel 4.3 menunjukkan bahwa lama rawat inap pasien ISPA dapat dikelompokkan menjadi tiga yaitu lama hari rawat inap $2-4$ hari, $5-7$ hari dan 8 10 hari. Pada waktu $2-4$ hari dengan 27 pasien mempunyai persentase 33,8 \%, pada waktu $5-7$ hari dengan 42 pasien mempunyai persentase sebesar $52,5 \%$ dan $8-10$ hari sebanyak 11 pasien dengan persentase 13,8\%. Lama hari rawat inap pada pasien di RSUD Kajen Kabupaten Pekalongan periode Jauari - Desember 2019 yang mempunyai persentase paling banyak yaitu pada lama rawat inap $5-7$ hari dengan jumlah pasien sebanyak 42. Hal ini sesuai dengan pedoman pengobatan ISPA dimana antibiotik diberikan dan dimonitoring selama 24 jam sampai 72 jam serta pemberian pengobatan 5 - 7 hari (Kemenkes RI, 2011).

Pola pengobatan pasien ISPA berdasarkan antibiotik di RSUD Kajen Kabupaten Pekalongan terdapat dua jenis golongan antibiotik diantaranya ialah golongan sefalosporin dan golongan penisilin. Dari hasil penelitian diatas jenis antibiotik yang paling banyak digunakan ialah antibiotik cefotaxim injeksi dengan 51 pasien persentase sebesar 63,7 \%, efotax sebanyak 11 pasien persentase 13,8 \%, viccillin injeksi sebanyak 13 pasien dengan persentase $16,3 \%$, ampicillin 1 pasien persentase 1,3\%, cefadroxil sirup 2 pasien presetase 2,5\% dan cefixim sirup 2 pasien persentase 2,5\%. Menurut Utami (2017) menjelaskan bahwa antibiotik golongan sefalosporin dan penisilin bersifat bakterisid, meknisme kerja antibiotik tersebut dengan cara merusak dinding sel atau menghambat sintesis peptioglikan yaitu heterpolimer dengan memberikan stabilitas mekanik pada dinding sel bakteri.

Jenis antibiotik yang memiliki rata - rata biaya paling besar adalah pada antitbiotik Efotax yaitu, Rp. 278.690dengan jumlah pasien 11. Sedangkan biaya rata - rata antibiotik paling kecil adalah pada antibiotik Cefadroxil sirup Rp. 12.800 dengan jumlah pasien 2. Jumlah pasien penggunaan antibiotik terbanyak yaitu pada antibiotik Cefotaxim jumlah pasien 51 dengan rata - rata biaya sebesar Rp. 31.781. Jika dilihat dari banyaknya jumlah pasien yang menggunakan terapi antibiotik, maka Cefotaxim merupakan pilihan terapi antibiotik yang baik dengan rata - rata biaya sebesar Rp. 31.781

Dari hasil Tabel 4.6 dapat dilihat pada biaya medik langsung yang paling tinggi pada pasien ISPA yaitu pada antibiotik efotax injeksi, sebesar Rp. 1.392.189 sedangkan biaya yang paling rendah adalah antibiotik cefadroxil sirup sebesar Rp. 850.564. Adanya perbedaan biaya medik langsung dari masing - masing pengobatan dikarenakan lamanya pasien dirawat serta harga dari masing-masing antibiotik antara antibiotik injeksi dan oral berbeda

Pada Tabel 4.7 bahwa nilai persentase efektivitas tertinggi yaitu pada terapi antibiotik Cefotaxim injeksi dengan persentase sebesar 52,90\% adapun jumlah pasien yang mencapai target sebanyak 27 pasien. Pada terapi antibiotik Efotax persentase sebesar 54,50 \% dengan jumlah pasien yang mecapai target sebanyak 6 pasien. Pada terapi antibiotik Viccillin injeksi persentase sebesar 61,50 \% dengan jumlah pasien yang mencapai target sebanyak 8 pasien. Sedangkan pada terapi antibiotik Ampicillin injeksi, Cefadroxil sirup dan Cefixim sirup tidak mempunyai jumlah pasien yang mencapai target lama rawat inap, hal ini dikarenakan jumlah pasien yang 


\section{Prosiding Seminar Nasional Kesehatan 2021 Lembaga Penelitian dan Pengabdian Masyarakat Universitas Muhammadiyah Pekajangan Pekalongan}

menggunakan terapi antibiotik Ampicillin injeksi, Cefadroxil sirup dan Cefixim sirup sedikit, sehingga nilai persentase efektivitas terapi 0,00\%.

Berdasarkan hasil perhitungan nilai ACER bahwa penggunaan terapi antibiotik pada pasien ISPA yang paling cost effective adalah pada terapi antibiotik Cefotaxim injeksi dengan nilai ACER terendah sebesar Rp. 1.545.164 dibandingkan dengan penggunaan terapi antibiotik lain. Semakin rendah nilai ACER pada penggunaan terapi pengobatan maka semakin cost effective pada terapi obat tersebut (Andayani, 2013).

Hasil perhitungan ICER perbandingan antara Viccillin injeksi dengan Cefotaxim injeksi mempunyai nilai ICER sebesar Rp. 6.968.465 hal ini dapat dikatakan bahwa perbandingan antara kedua obat tersebut memiliki tambahan biaya sebesar Rp. 6.968.465 dalam meningkatkan efektivitas per satuan unit. Pada hasil perhitungan ICER perbandingan antara Cefotaxim injeksi dengan Efotax mempunyai nilai ICER sebesar Rp. - 63.081.937 dari perhitungan ini apabila diperoleh hasil negatif maka obat tersebut merupakan pilihan terapi yang terbaik (Andayani, 2013). Dapat disimpulkan bahwa Cefotaxim injeksi merupakan terapi antibiotik yang paling efektiff digunakan pada pasien ISPA di RSUD Kajen Kabupaten pekalongan periode Januari - Desember 2019

\section{Kesimpulan}

Aantibiotik yang digunakan pasien ISPA terdapat beberapa golongan diantaranya adalah golongan sefalosporin dan golongan penicillin, pada golongan sefalosporin yaitu Cefotaxim, Efotax, Cefadroxil dan Cefixim. Golongan penisilin yaitu Ampicillin dan Viccillin. Aantibiotik Cefotaxim mempunyai nilai ACER sebesar Rp 1.545.164, pada antibiotik Efotax nilai ACER sebesar Rp 2.554.475 dan antibiotik Viccillin sebesar Rp 2.144.452. Nilai ICER yang paling kecil terdapat pada perbandingan antara Cefotaxim injeksi dengan Efotax sebesar Rp - 63.081.937Pada perbandingan antara Efotax dengan Cefotaxim nilai ICER sebesar Rp. 6.968.465

\section{Referensi}

[1] Ade Saputra Nasution, (2020). Aspek Individu Dengan Kejadian ISPA DiKelurahanCibatat Cimahi. Universitas Airlangga. DOI: 10.20473/amnt.. v4i2.2020.103-108.

[2] Andayani T.M., (2013). Farmakoekonomi Prinsip dan Metodologi, Bursa ilmu. Yogyakarta.

[3] Departemen Kesehatan RI, (2013). Riset Kesehatan Dasar. Badan Penelitian dan Pengembangan Kesehatan Kementrian Kesehata, Jakarta : Departemen kesehatan RI.

[4] Dinas Kesehatan Kabupaten Pekalongan, (2019) Prevalensi Sepuluh Penyakit Terbesar Di Kabupaten Pekalongan tahun 2019, Kajen: Dinas Kesehatan Kabupaten Pekalongan.

[5] Dinas Kesehatan Provinsi Jawa Tengah, (2019) Profil kesehatan Provinsi Jawa Tengah Tahun 2019. Semarang : Dinas Kesehatan.

[6] Hufman, Edna K. Health Information Mangement. Phisicians Record Compani Berwyn Illions: 1994. 


\section{Prosiding Seminar Nasional Kesehatan 2021 Lembaga Penelitian dan Pengabdian Masyarakat Universitas Muhammadiyah Pekajangan Pekalongan}

[7] Kaparang, P. C., Tjitrosantoso, H. \& Yamlean, P. V. 2014. Evaluasi Kerasionalan Penggunaan Antibiotika Pada Pengobata Pneuomnia Anak Di Instalasi Rawat Inap RSUP Prof. Dr. R.D Kanduo Manado Periode Januari - Desember 2013. Pharmacon Jurnal IImiah Farmasi, 3,247-254.

[8] Kementerian Kesehatan Republik Indonesia.(2011). Pedoman Pelayanan Kefarmasian Untuk Terapi Antibiotik. Jakata: Kementerian Kesehatan RI.

[9] Kementerian Kesehatan Indonesia, (2014), Standar Pelayanan Kesehatan DalamPenyelenggaraan Program Jaminan Kesehatan. Jakarta : Kementerian kesehatan RI.

[10] Kementerian Kesehatan Indonesia, (2017), Data Dan Informasi Profil Kesehatan RI. Jakarta : Kementerian Kesehatan RI.

[11] Kementerian Kesehatan Indonesia, (2018), Profil kesehatan RI. Jakarta: Kementerian Kesehatan RI.

[12] Menteri Kesehatan Republik Indonesia, (2018) Keputusan Menteri Kesehatan Nomor : 44 Tahun 2018 Tentang Promosi Kesehatan Rumah Sakit, Jakarta : Menteri kesehatan.

[13] Putri Kalpana Bella, Yulian Wahyu Permadi, Rini Kristiyanti dan Wulan Agustin Ningrum (2020). Analisis Efektivitas Biaya Terapi Penggunaan Antibiotik Sefotaksim Dan Sefiksim Pada Pasien Diare Akut Anak Di Rawat Inap RSUD Kraton Kabupaten Pekalongan Januari 2018 - April 2020.Skripsi.Fakultas Ilmu Kesehatan Universitas Muhammadiyah Pekajangan Pekalngan.

[14] Rumah Sakit Umum Daerah Kajen, (2018). Profil RSUD Kajen:Kajen. Kabupaten Pekalongan.

[15] Sugiyono, (2014). Metode Penelitian Pendidikan Pendekatan Kuantitatif, Kualitatif Dan R\&D. Bandung: Alfabeta.

[17] UtamiAnandaYulita, Muhammad Akib Yuswar \& Ressi Susanti. (2017). Gambaran Penggunaan Antibiotik Dan PTO (Permasalahan Terkait Obat) Pasien ISPA (Infeksi Saluran Pernafasan Akut) Anak Rawat Inap Di RSUD dr. Soedarso Pontianak Tahun 2017. Skripsi. Program Studi Farmasi Fakultas Kedokteran Universitas Tanjung Pura Pontianak. 